\title{
Changes in conjunction usage in Abha Arabic dialect: A sociolinguistic study ${ }^{(*)}$
}

\author{
Munira A. Al-Azraqi \\ Department of English, College of Arts, University \\ of Dammam, Saudi Arabia
}

الماخص

\begin{abstract}
Abstract

The usage of particles in Abha dialect, which is spoken in southwest Saudi Arabia, is changing rapidly as a result of greater access of the new generation to education and communication. Many conjunctions seem to be in danger of being lost forever. As part of an investigation into the presence of conjunctions in Abha dialect, a total of 80 native speakers of the dialect, randomly selected, have been asked to complete a questionnaire with the objective of tracing shifts and patterns in the usage of conjunctions. The questionnaire consisted of two sections covering the use of conjunction in sentences based on scenarios. The participants were asked to choose the sentence they use regularly. The results showed that there is a kind of levelling of usage which is shown in the low rate of using some conjunctions for others. The use of conjunctions in Abha dialect varies between the older and younger generations and also between educated and uneducated speakers. This variation implies that the conjunctions preferred by the older generation will fall into disuse and may be lost completely in the coming years. This is particularly evident where there is more than one particle with the same sense and function.
\end{abstract}

${ }^{(*)}$ Bulletin of the Faculty of Arts Volume 79 Issue 2 January 2019 
Keywords: Abha dialect, conjunction, koinization, coordinators, subordinators, Social factors.

\section{Introduction}

A wide range of particles are present in the Abha dialect of today as a result of dialect contact (Al-Azraqi, 2014; 2016). People from villages in various parts of the southwest Arabian Peninsula, with different spoken dialects, began to migrate and settle in the valley of Abha from the mid-nineteenth century onwards. Communication among these different peoples has resulted in a distinctive dialect in Abha Valley; a number of linguistic variants that were features of these other dialects have become part of the mix that is the present-day Abha dialect. Some of these variants are syntactic and include, for example, the use of demonstrative pronouns, relative pronouns, question words, and particles (Al-Azraqi, 1998).

Britain and Trudgill (1999) point out that when mutually intelligible but distinct dialects of the same language come into contact, items from each dialect may be incorporated into the other, in a process of linguistic accommodation. They add that, when this contact is longterm, such as when English speakers from different dialect areas of the United Kingdom became resident in Australia and New Zealand, or when dialect contact results from the development of new towns, linguistic accommodation can become permanent and a new dialect can emerge. This process of 'koineization', as Kerswill (2002) refers to it, can take place relatively swiftly; it may take only two or three generations to complete, see also (Kerswill, 2006; Kerswill \& Williams, 2005). Siegel (1985) claims that the development of a 'koine' is characterized by reduction and simplification, which are processes that lead to a decrease in the referential or non-referential potential of a language. 
Munira A. Al-Azraqi: Changes in conjunction usage in Abha Arabic 27

There is evidence to suggest that particles in Abha dialect such as coordinating and subordinating conjunctions (coordinators and subordinators), response particles, negative particles, and even articles, are becoming simplified which may be an indication of koineization. For instance, Al-Azraqi (2014) found that gid, which is one of the particles used in Abha dialect in various syntactic forms, has lost some of its functions. In some cases, particles have even disappeared. AlAzraqi (2016) concludes that Koineization seems to be occurring in this dialect, leading to levelling and simplification of some features. In her study, it has been shown that the negator $m \bar{a}$ substitutes the other negators lis, lim and $l \bar{a}$ in some contexts in both verbal and non-verbal predications, particularly among the younger generation.

The case seems to be similar for conjunctions; some subordinators and coordinators seem to be less frequently nowadays, and some are even disappearing from everyday speech. In particular, young educated speakers who are third-generation immigrants, seem to be limiting their use of some conjunctions. The changes that appear to be taking place in Abha dialect have not been documented formally, this study, therefore set out to examine these changes regarding the use of conjunctions.

Hinskens (1998) researched dialect levelling in the Dutch province of Limburg. Based on his findings, he argues that dialect levelling does not necessarily lead to convergence with the Standard language and, in some cases, there is even divergence. There is a common assumption that the direction of change seen in modern Arabic dialects, which is towards Modern Standard Arabic (MSA), can be explained by the social prestige of MSA in addition to people's greater exposure to it as a result of its use in the media and education (Gibson, 2002). In Gibson's study on dialect levelling in Tunisian Arabic, which focused on four variables, he found that the behaviour of Tunisian speakers concerning the use of /q/ is consistent with this hypothesis, whereas the other three cases he investigated are changing towards another dialect rather than MSA. Trudgill (1986) suggests that the situations that involve transplantation and contact between mutually intelligible dialects lead to the development of new dialects. The specific qualities 
that distinguish the variants of the different dialects are reduced until only one variant, remains. This one variant often contains some of the qualities of each of the original dialects. Al-Azraqi (2014; 2016) conclude that Abha dialect is through simplification and levelling processes. Before moving on to the explicit aim of this study in relation to the usage of conjunctions in Abha dialect, some historical background on the city and its people is provided.

\subsection{Abha, the city and its people}

Before the nineteenth century Abha was not a city but a collection of villages within Abha Valley. As this collective became concentrated in one area, Abha began to be known as a city and in AH1242/AD1827, Abha was selected as the capital of the government of Asīr, led by Ali al-Mugēēī. After that time, Abha grew in size and population, particularly during the Ottoman period (AH1289/AD1872 to AH1336/AD1918), and it continued to increase during the Saudi period (from AH1338 AH1920 to the present day) (Jrais, 1997); (AlAzraqi, 2014,2016).

As in other parts of Saudi Arabia, as Abha developed, many people from nearby and distant villages have migrated to the city aiming jobs and better services, bringing with them their own local dialects. The early settlers in Abha came from nearby tribes such as the Ban̄̄ Muḡèd, Alkam, Rabī'ah w-Rfēdah, and Banī-Mālik as well as from tribes and villages further afield such as Qahțān, Shahrān, Rijāl 'alma' and others (An-Ni 'mī (n.d); Shākir, 1981; Hamzah, 1968), see also (Al-Azraqi, 1998; 2014; 2016).

In Abha, people of different tribal origins do not usually live in separate groups. Many of them retain strong communicative ties with their relatives in their villages, but this does not translate into separate communities in Abha itself. The various groups do not have closed neighbourhoods; any neighbourhood might be home for people of different tribal origins. People communicate at work, at school, and in public places. The different tribal groups and Abha community as a 
Munira A. Al-Azraqi: Changes in conjunction usage in Abha Arabic 29

whole appear to be well-integrated. This usually causes mixing and levelling of the dialects (Chambers \& Trudgill, 1980). Indeed, it is not always possible to determine a speaker's tribal origin, especially when the individual is a third-generation immigrant, not least because of the unified dialect that Abha speakers tend to use nowadays, see (AlAzraqi, 2014; 2016).

\subsection{Conjunctions in Standard Arabic and Abha dialect}

In the standard Arabic and Abha dialect, subordinators and coordinators are particles that do not exhibit morphological contrast, i.e., they do not inflect. They do not take the definite article. They have no complete meaning in themselves, so they depend on other parts of speech to complete their meaning (Eid, 1991). Az-Zamaxsharī (1859) defines the particle as that which indicates a meaning in other parts of speech and always requires a verb or a noun. The main feature of these conjunctions, which distinguishes them from all other parts of speech, is that they never function as the subject, object, predicand, or predicate. They mainly conjoin. Badawi et al. presents a detailed analysis for the structure of coordination and subordination in Written Arabic which shows the wide range of subordinators and coordinators in Arabic (Badawi et al., 2004: 295-303; 539-574; 575-634). There is a wide range of conjunctions in Abha dialect as well. They are used in everyday speech by speakers of Abha dialect. Each set of conjunctions constitutes a closed system (Al-Azraqi, 1998).

\section{Aim of the Study: An assessment of the Usage of Conjunctions in Abha Dialect}

As we have seen above, the mixing of the dialects due to the influx over time of various tribal and village groups into Abha introduced many particles into the local dialect. However, as a result of changes to life style and greater communication and modernization, some of those conjunctions seem to have disappeared, whereas others have survived.

The present study considers age and education level as factors that 
may be important in language change. Age reflects language contact. Old people retain their original dialect more than younger ones. Level of education, on the other hand, manifests the effect of education on dialect change. It is hypothesized that level of education and age both play a role in explaining the shifts in and extent of conjunction usage, specifically of subordinators and coordinators. Today, most of the youth and young to middle-aged adults are educated at least until high school level. Older people, however, are more likely to be uneducated because the provision of formal education in Abha only began when the first school opened in 1936 (Jrais, 1995).

\section{Methodology}

A total of 80 participants were involved in this study. They were randomly selected. Four assistants distributed a questionnaire in their schools, universities, and neighbourhoods, to local people only. Participants were asked to complete the questionnaire, which consisted of a section covering the use of coordinators and a section covering the use of subordinators in sentences based on scenarios. For each item, the participants were asked to choose the sentence they use regularly. Some of the sentences were part of the data that were collected for the researcher's $\mathrm{PhD}$ in 1998 and for other following studies on this dialect. The questionnaires were returned by e-mail, via the online survey tool, Survey Monkey, and in person. The data were analysed using MS Excel 2010.

Some of the participants were interviewed personally by the researchers or by one of the assistants, and this was especially for those who could not read. The interviews were recorded using Olympus LS11 and the data were saved in WAV lossless format $(44,000 \mathrm{~Hz}, 16$ Bit). The same questionnaire was used during the interview. There was a good distribution of participants with different levels of education and of different ages.

The potential influence of two social variables was investigated in this study. Age was considered, on the basis of the claim that looking at 
Munira A. Al-Azraqi: Changes in conjunction usage in Abha Arabic $\underline{31}$

linguistic differences between speakers of different ages facilitates the study of linguistic change. The 80 participants in this study were aged from 20 to 70 years. For analysis, they were divided into five groups, as shown in Table 1. A range of 10 years was considered suitable because this range seems to capture the common features of the different age groups.

Table 1: Age of participants

\begin{tabular}{|c|c|}
\hline Age & No. of participants \\
\hline $20-31$ & 18 \\
\hline $31-40$ & 18 \\
\hline $41-50$ & 17 \\
\hline $51-60$ & 13 \\
\hline $61-70$ & 14 \\
\hline Total & $\mathbf{8 0}$ \\
\hline
\end{tabular}

The participants were also grouped according to their level of education into (i) educated (those who have finished at least high school); (ii) semi-educated (those who could read and write fluently, regardless of whether or not they had any formal education); and (iii) uneducated (those who could not read or write, or could read but only poorly). The breakdown of these groups is shown in Table 2 .

Table 2: Educational level of participants.

\begin{tabular}{|c|c|}
\hline Education & No. of participants \\
\hline Educated & 30 \\
\hline Semi-educated & 31 \\
\hline Uneducated & 19 \\
\hline Total & $\mathbf{8 0}$ \\
\hline
\end{tabular}

In Saudi Arabia, differences in people's educational levels are 
reflected in many patterns of social behaviour, including their use of language. Hence, level of education is an important indicator when studying dialects in Saudi Arabia. Semi-educated and uneducated people are likely to use a very local dialect that is unaffected by the standard variety of Arabic because people are exposed to standard Arabic almost exclusively through education, as explained above. Table 3 shows the symbol used to transliterate the examples in this study.

Table 3: Consonants and vowels in Abha Dialect

\begin{tabular}{|c|c|}
\hline Consonants/Vowels & Description \\
\hline$b$ & voiced bilabial stop \\
\hline$f$ & voiceless labiodental fricative \\
\hline$t$ & voiceless alveolar stop \\
\hline$\underline{t}$ & emphatic alveolar stop \\
\hline $\boldsymbol{\theta}$ & voiceless interdental fricative \\
\hline$d$ & voiced alveolar stop \\
\hline ठ & voiced interdental fricative \\
\hline$d$ & emphatic voiced interdental fricative \\
\hline$s$ & voiceless alveolar fricative \\
\hline $\boldsymbol{s}$ & emphatic voiceless alveolar fricative \\
\hline$z$ & voiced alveolar fricative \\
\hline $\int$ & voiceless alveo-palatal fricative \\
\hline$j$ & voiced alveo-palatal affricate \\
\hline$g$ & voiced velar stop \\
\hline $\boldsymbol{k}$ & voiceless velar stop \\
\hline$q$ & voiceless uvular stop \\
\hline$\dot{\boldsymbol{g}}$ & voiced uvular fricative \\
\hline$x$ & voiceless uvular fricative \\
\hline$l$ & voiced alveolar lateral \\
\hline
\end{tabular}


Munira A. Al-Azraqi: Changes in conjunction usage in Abha Arabic $\underline{33}$

\begin{tabular}{|l|l|}
\hline $\boldsymbol{r}$ & voiced alveolar flap \\
\hline $\boldsymbol{m}$ & voiced labial nasal \\
\hline $\boldsymbol{n}$ & voiced alveolar nasal \\
\hline $\boldsymbol{w}$ & voiced labio-velar approximant \\
\hline $\boldsymbol{y}$ & voiced palatal approximant \\
\hline $\boldsymbol{h}$ & voiced pharyngeal fricative \\
\hline $\boldsymbol{P}$ & voiceless pharyngeal fricative \\
\hline $\boldsymbol{h}$ & glottal stop \\
\hline $\boldsymbol{a}$ & voiceless glottal fricative \\
\hline $\boldsymbol{i}$ & open low vowel \\
\hline $\boldsymbol{u}$ & closed high front vowel \\
\hline$\overline{\boldsymbol{a}}$ & closed high round back vowel \\
\hline$\overline{\boldsymbol{e}}$ & Long open low vowel \\
\hline $\boldsymbol{\boldsymbol { l }}$ & Long mid front vowel \\
\hline$\overline{\boldsymbol{u}}$ & Long closed high front vowel \\
\hline & long closed high round back vowel \\
\hline
\end{tabular}

\section{Results and Discussion}

The numerous conjunctions used in Abha dialect conjoin words, phrases, clauses, and sentences. Sometimes, they conjoin more than one syntactic item depending on the kind of coordinator used, as discussed in Sec. 4.2. Subordinators precede independent clauses or sentences. They indicate time, place, manner, cause and reason, and concession, as discussed in detail below. Some sets have variants and are used differently depending on social variants as age and education level.

The results of the study are presented in the following sections; first coordinators, and then subordinators, including those indicating time, place, manner, concession, and cause and reason 


\subsection{Coordinators}

Some coordinators such as wa, Paw/walla, Pamma....aw/walla and hem/hum, conjoin words, phrases, clauses, and sentences, while others such as $f / f a / f \dot{g} \bar{e} r$, bass, and läkin conjoin only clauses or sentences. Table 4 provides an English translation of these coordinators.

Table 4: Coordinators in Abha dialect.

\begin{tabular}{|c|c|}
\hline Coordinators & Gloss \\
\hline$w / w a / w u$ & and \\
\hline Paw/wallā & or \\
\hline Pammā.... Paw/walla & either ... or \\
\hline$f / f a, f \dot{g} \bar{e} r / \dot{g} \bar{e} r / h i m \dot{g} \bar{e} r$ & then, so \\
\hline $\begin{array}{l}\text { baßdēn, xalf, Sawwad, } \\
\text { eumman }\end{array}$ & then \\
\hline läkin, bass, $\dot{g} \bar{e} r$ & but \\
\hline him/hem/hum & $\begin{array}{l}\text { then, after that (to conjoin sentences } \\
\text { when telling a story or relating an } \\
\text { event in sequence) }\end{array}$ \\
\hline ha/haw & $\begin{array}{l}\text { and (in relating an event or story, to } \\
\text { talk about something that should have } \\
\text { been mentioned before) }\end{array}$ \\
\hline
\end{tabular}

Some coordinators have no variables and are used therefore by most Abha speakers. The coordinators $w$ and Paw/walla are used almost equally. They syntactically conjoin items such as syntactically equal words, phrases, clauses, or sentences. wa coordinates parallel notions, whereas Paw/walla conjoins contrastive or alternative notions. Consider the following examples:
?axað kutubah
"he took his his books and
w Pag̀rāđah kullahā all his stuff." 
Munira A. Al-Azraqi: Changes in conjunction usage in Abha Arabic $\underline{35}$

$$
\begin{aligned}
& \text { ruћ luhum wallā } \text { ?ug fud "go to them or stay with us." } \\
& \text { maßn̄ }
\end{aligned}
$$

Other coordinators are equivalent in meaning and are used in similar contexts. These are the focus of our investigation. In the present-day, these coordinators are used differently depending on social variables such as age and level of education as discussed below. First, let us look at Pammā....'aw/walla $\bar{a}$, which usually conjoins two items. It implies alternation. It can coordinate words, phrases, clauses, or sentences (Al-Azraqi, 1998). Consider the following examples:

$$
\begin{aligned}
& \text { ruћ fuf bitlāgī Pammā Ghazi "go, you will see either Gazi } \\
& \text { walla Ahmad or Ahamd." } \\
& \text { Rixtār Pammā l-madrasah "choose either the school or } \\
& \text { walla } l \text {-warfah the workshop." }
\end{aligned}
$$

There is variation in the level of usage of Paw and walla among speakers of different ages and education levels, as shown in Figures 1 and 2.

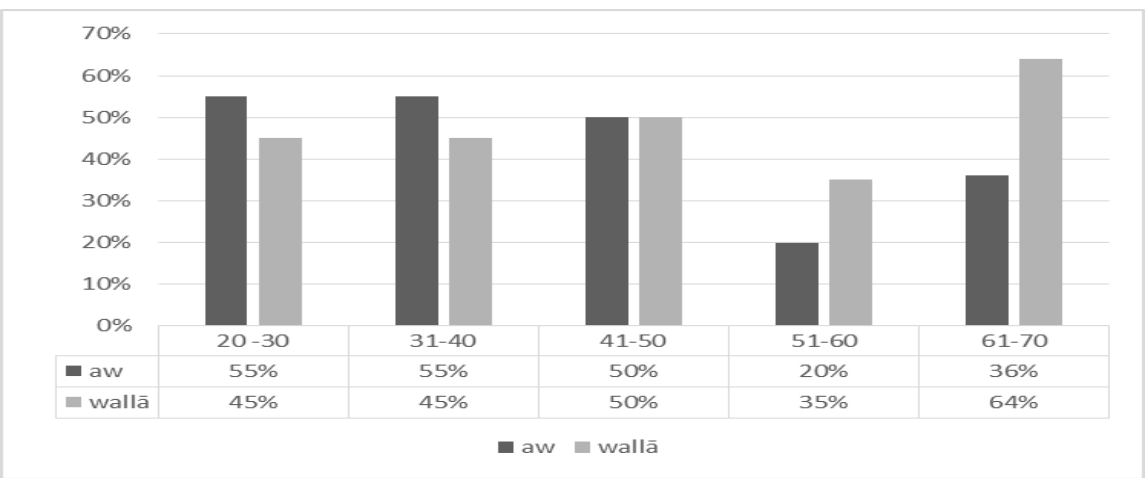

Figure 1: Average percentage of responses in which Paw and walla are used according to age group. 


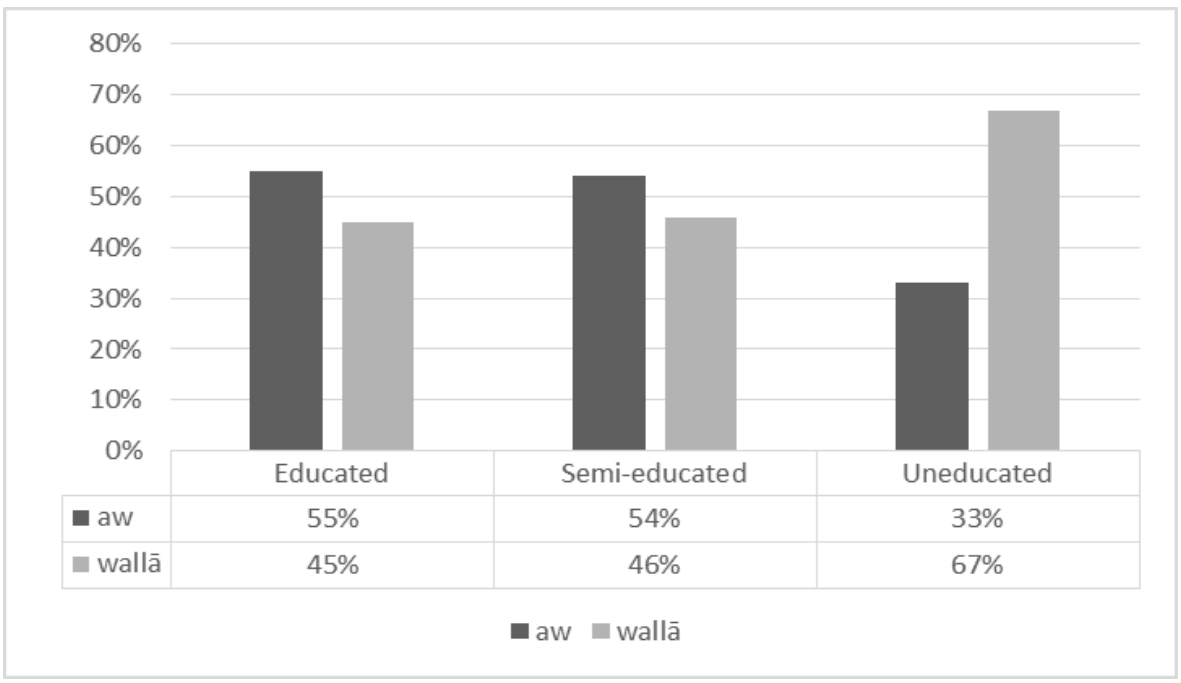

Figure 2: Average percentage of responses in which $\mathrm{Paw}_{\mathrm{w}}$ and walla are used according to level of education.

Figures 1 and 2 show that both walla and aw are used by most speakers, however, walla is less frequently used among younger and educated speakers.

On the other hand, the conjunctions $f / f a$ and $\dot{g} \bar{e} r$ are used to conjoin clauses or sentences. Both can be combined as one word as figer and sometimes $\dot{g} \bar{e} r$ can be preceded by him as in himg $\bar{e} r$. They imply sequence and consequence. $f / f a$ is still used widely among Abha speakers for both purposes, as shown in the examples below: matā xalașat $\mathbf{f}$ a țīhā il- "..when she finishes, then waragah give her the paper."

sa?alatnī $\mathrm{f}$ gult lhā Salā "she asked me, then I told kull fay her everything."

$\dot{g} \bar{e} r / f \dot{g} \bar{e} r / h i m \dot{g} \bar{e} r$ are mostly used in telling stories or in relating the details of long events. Their usage is intended to carry the sense of 
Munira A. Al-Azraqi: Changes in conjunction usage in Abha Arabic $\underline{37}$

suddenness and surprise:

daxal Salènà bagta(h) fìger gumū "he came in suddenly, so the ya n-niswān yitfäradūn women ran away."

yōm fâf il-bint gid hī bitțit, "when he saw the girl going to himġēr gum w msakhā fall, he jumped up and caught her."

An analysis of the data shows that older and less educated people tend to use $\dot{g} \bar{e} r / f \dot{g} \bar{e} r / h i m \dot{g} \bar{e} r$ more than younger people. Younger speakers use the short form $\mathrm{f} / f a$ instead, see Figures 3 and 4.

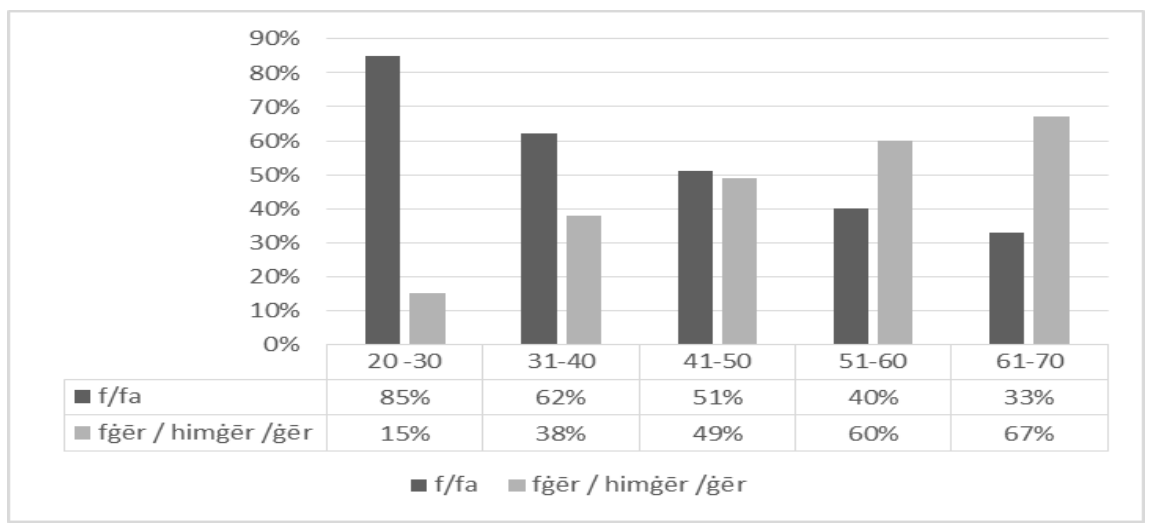

Figure 3: Average percentage of responses in which $f / f a$ and $f \dot{g} \bar{e} r / h i m \dot{g} \bar{e} r / \dot{g} \bar{e} r$ are used according to age group.

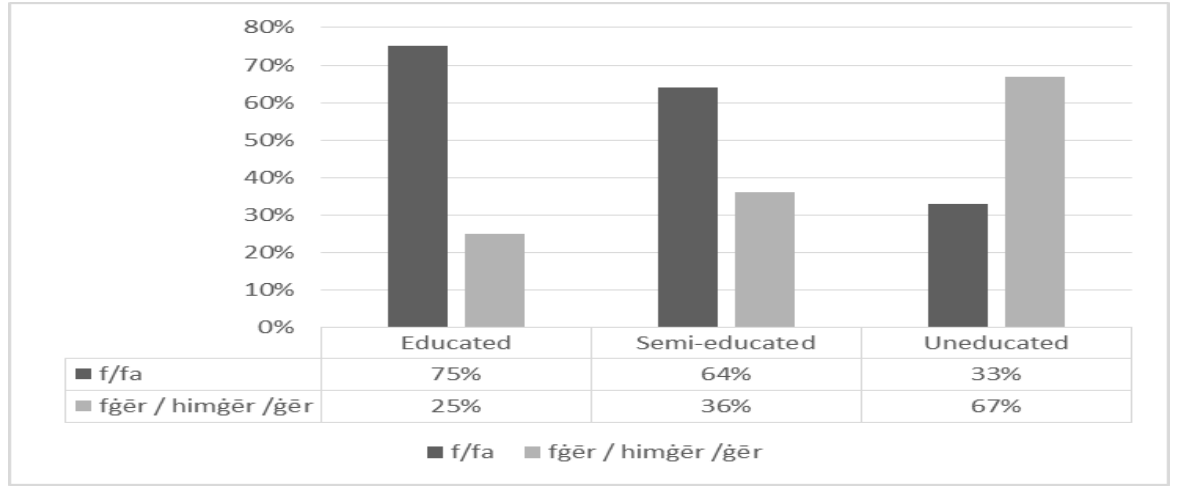

Figure 4: Average percentage of responses in which $f / f a$ and $f \dot{g} \bar{e} r / h i m \dot{g} \bar{e} r / \dot{g} \bar{e} r$ are used according to level of education. 
Similar to f/fa and $\dot{g} \bar{e} r / f \dot{g} \bar{e} r / h i m \dot{g} \bar{e} r$ above, ba Sdēn, xalf, Sawwad, and eumman usually denote sequence. They are often used to synchronize sentences when telling stories or describing long events. They carry the sense of sequence and are usually used to refer to things that happened later ${ }^{1}$. Consider the following examples:

\begin{tabular}{|c|c|}
\hline Sawwad rā $\hbar a w$ & "then they left" \\
\hline $\begin{array}{l}. \text { ba Sdēn kallamtahā } w \\
\text { Sazamtuhā }\end{array}$ & $\begin{array}{l}\text { "then (later) I called her and I } \\
\text { invited her." }\end{array}$ \\
\hline $\begin{array}{l}\text { aSdēn Pattafagn } \\
\text { maßhum }\end{array}$ & $\begin{array}{l}\text { "then we had a deal with } \\
\text { them." }\end{array}$ \\
\hline
\end{tabular}

The results show that baSden is used the most by people in general, whereas eamman is used the least, despite its sound which is closer to the standard Arabic as shown in Figures 5 and 6.

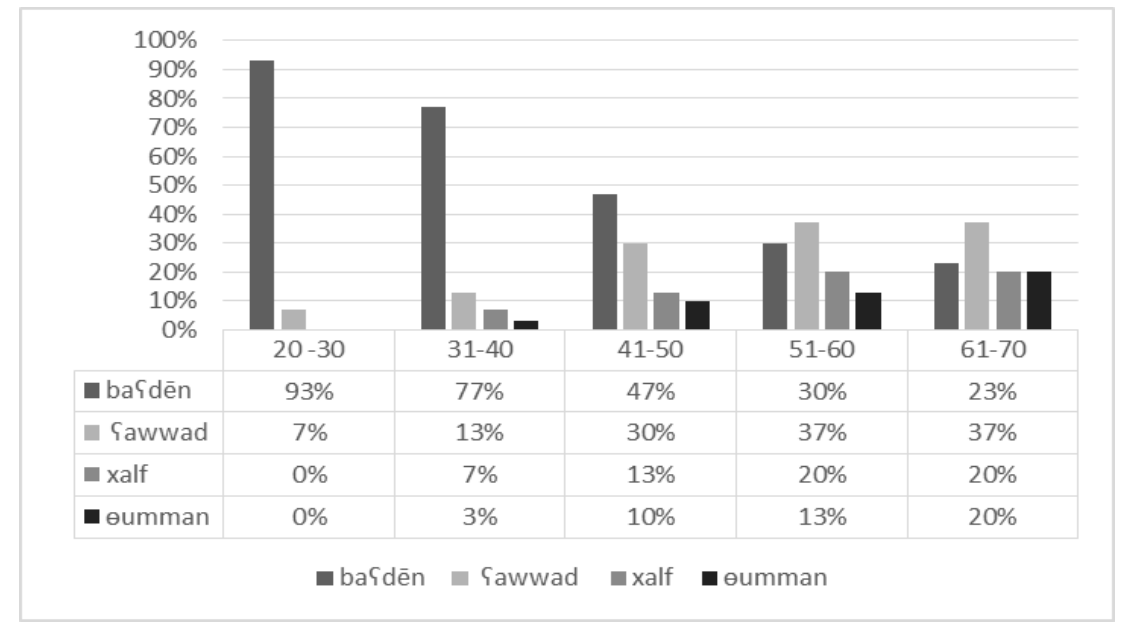

Figure 5: Average percentage of responses in which ba Sdèn, xalf, Sawwad, and eumman are used according to age group.

' baS dèn and xalf can sometimes function as adverbs in the sense of 'later',

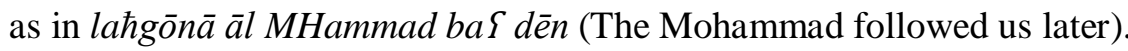


Munira A. Al-Azraqi: Changes in conjunction usage in Abha Arabic $\underline{39}$

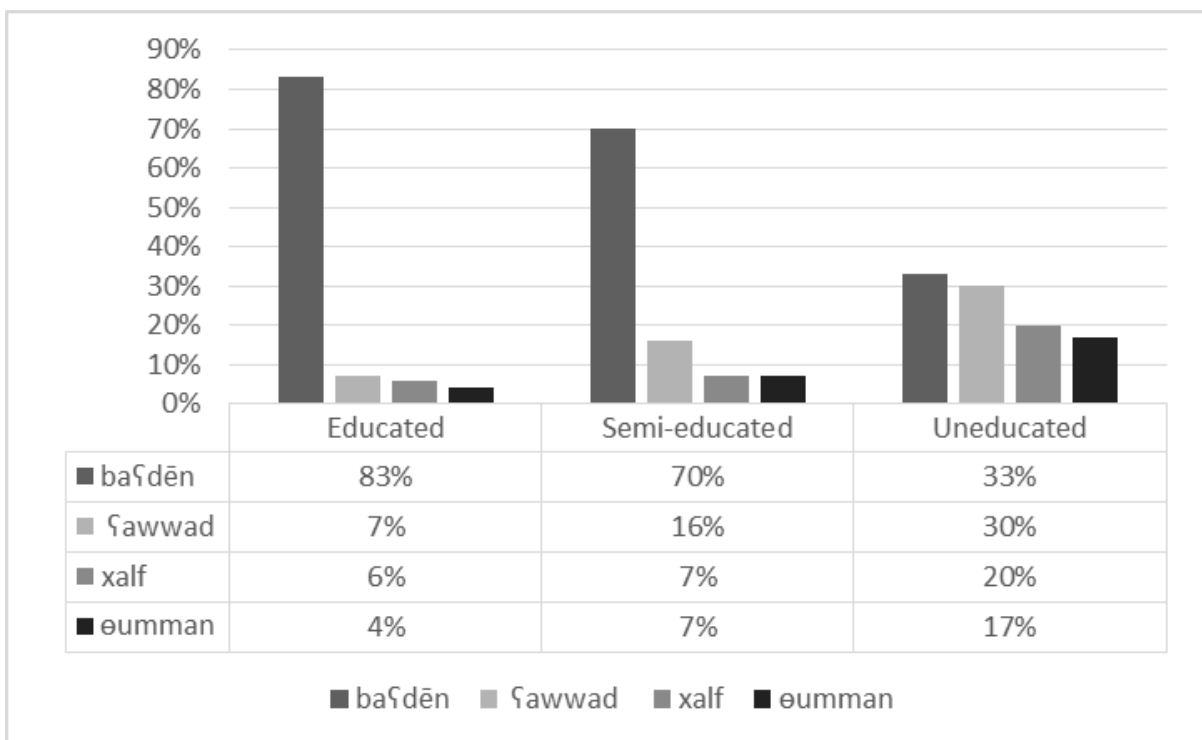

Figure 6: Average percentage of responses in which ba Sdèn, xalf, Sawwad, and eumman are used according to level of education.

bass, lākin and $\dot{g} \bar{e} r$ conjoin contrastive clauses. It should be noted that bass can also be used as an adverb with the meaning of 'only'. Watson (1993) describes this particle as a conjunct. Cowell (1964) also considers it to be a conjunct. Consider the following examples of the coordinators bass and läkin:

\begin{tabular}{|c|c|}
\hline hiyyah mā hī zìnah & \\
\hline $\begin{array}{l}\text { marrah bass } \\
\text { magbūlah }\end{array}$ & \\
\hline $\begin{array}{c}m \bar{a} \quad \text { yi rifah zīn läkin } \\
\text { biyis?al Sannah }\end{array}$ & $\begin{array}{l}\text { "he does not know hinm, but } \\
\text { he will ask about him." }\end{array}$ \\
\hline $\begin{array}{l}\text { allāh in Sādn } S \text { kasl, } \dot{\boldsymbol{g}} \overline{\boldsymbol{e}} \boldsymbol{r} \\
\quad \bar{e} \int \text { Pasawwì? }\end{array}$ & $\begin{array}{l}\text { "by God, I am still tired, but } \\
\text { what can I do?" }\end{array}$ \\
\hline
\end{tabular}

$\dot{g} \bar{e} r$, in this sense, is used the least among young educated speakers, whereas, it is still used among older uneducated and semi- 
educated speakers. bass is common in this dialect and is used commonly among the speakers. läkin is used more among the young educated speakers as shown in figures 7 and 8 .

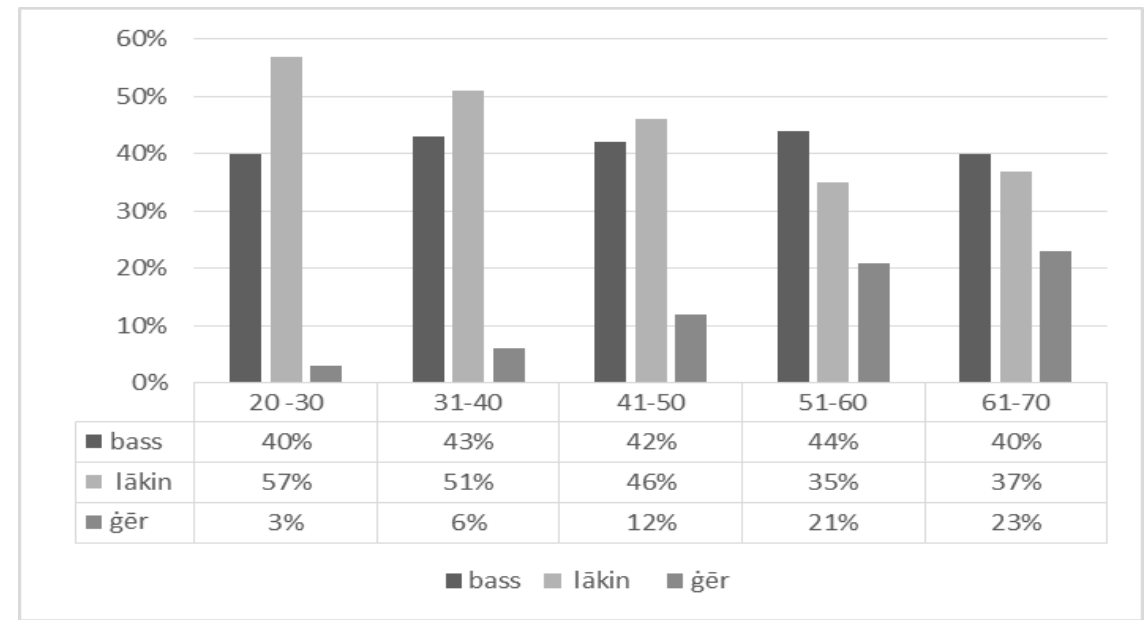

Figure 7: Average percentage of responses in which bass, $l \bar{a} k i n$ and $\dot{g} \bar{e} r$ are used according to age group.

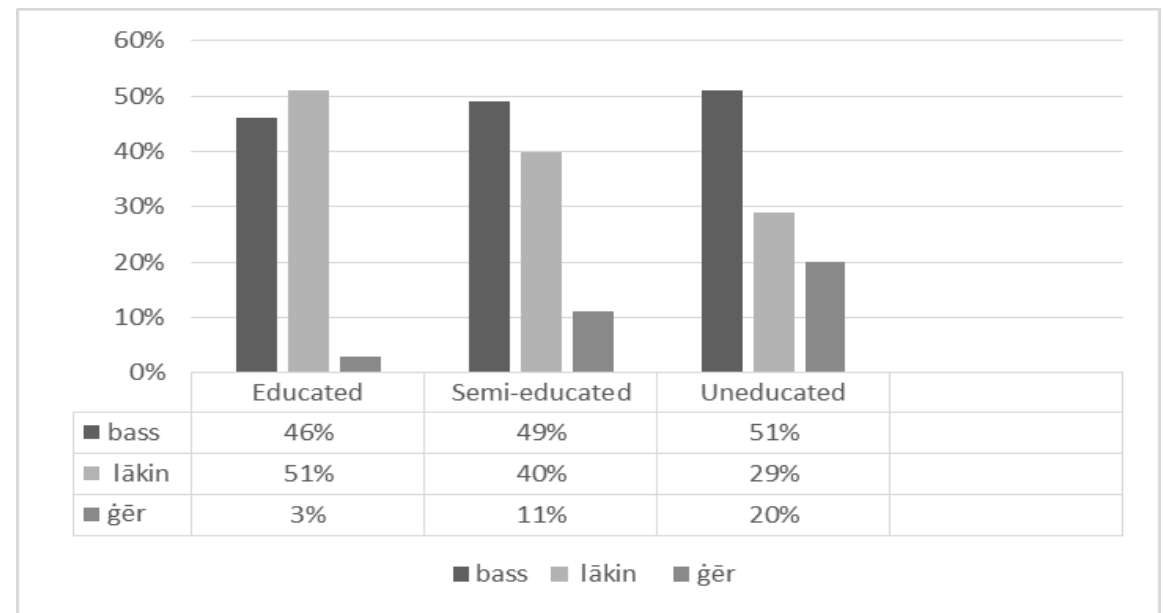

Figure 8: Average percentage of responses in which bass, läkin and $\dot{g} \bar{e} r$ are used according to level of education.

him/hem/hum and ha/haw show no major change. This is probably because they are used in specific meanings and functions. 
Munira A. Al-Azraqi: Changes in conjunction usage in Abha Arabic 41

him/hem/hum which is used to imply sequence and to conjoin sentences when telling stories are shown in the following examples:

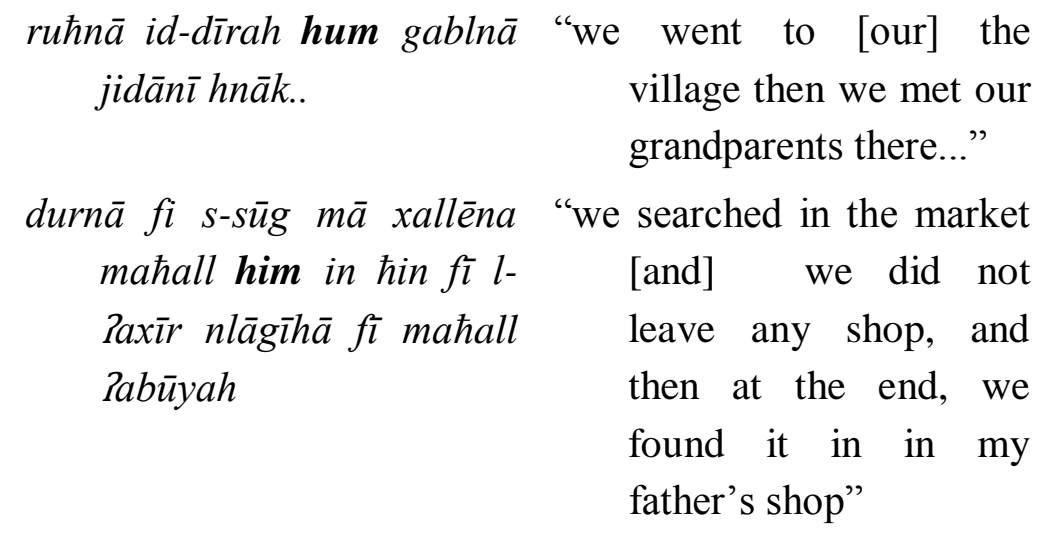

It should be noted here that him/hem/hum can be attached to le which is a presentational particle that functions in a similar manner to the standard $i \underline{d} \bar{a} b i$. They are used to express surprise or to describe something that has happened unexpectedly. $\bar{e}$ often occurs after the conjoins wa and him/hem/hum and gives the sense of 'suddenly there was...', (see Watson, 1993 for Rinn in Șan 'ānī Arabic and Al-Azraqi (1998) for Abha Arabic). hummale is found in the Sajmī dialect according to Johnstone (1961). hummale also has an equivalent in the Murra dialect, i.e., timmilāy or timmilē, according to Ingham (1994). I would suggest that the Murra particle consists of the conjoin tim, which is equivalent to the standard tumma (then) plus the presentational particle $l \bar{e}$ which occurs in the Abha, SAjmī, and the Murra dialects. Consider the following examples of hummale in the Abha dialect:

daxalnā l-majlis nabg் nag Gud "we entered the sitting room hummale gid hū malyān to sit, but [surprisingly] it was full."

ruћnā lah Salā mawidnā "we went according to our hummale $m \bar{a} h \bar{u}$ fìh appointment [with him] but [unexpectedly] he was not there" 
ha/haw is used to recall something that the speaker should have mentioned earlier. It is often used in telling stories. What is mentioned in the second clause, is introduced by ha/haw (Al-Azraqi, 1998). This particle is still in use among most of the Abha dialect speakers. Consider the following examples:

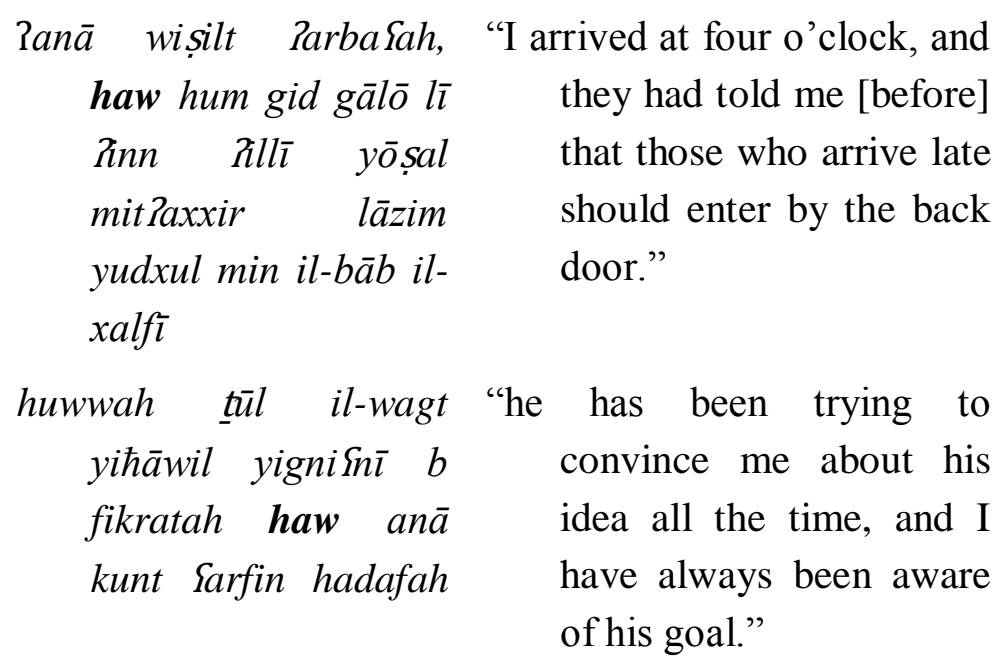

\subsection{Subordinators}

Abha dialect has a good variety of subordinators that are still used variably. They are discussed in the following sections with a focus on their usage according to the social factors of age and level of education. They are grouped according to their functions in the sentence, namely to denote time, place, manner, concession, and cause and reason.

\subsubsection{Time}

In Abha dialect, there are different subordinators to indicate the time of an action or event. Each one usually carries a specific meaning and function; however, some share similar meanings and functions, which means that there is a possibility that some 
Munira A. Al-Azraqi: Changes in conjunction usage in Abha Arabic 43

subordinators may be replaced by others due to sociolinguistic environment (al-Azrqi, 1998). Table 5 provides a list of the subordinators that are used in Abha dialect and the English translation:

Table 5: Subordinators of time in Abha dialect.

\begin{tabular}{|c|c|}
\hline Subordinator & Gloss \\
\hline$s \bar{a}$ Yatmō & when (lit. the time (hour) of) \\
\hline wagtma & when (lit. in the time of) \\
\hline hazzatmā & in the moment of, when \\
\hline gablmā & before \\
\hline ba $\{d m \bar{a}$ & after \\
\hline lēn/ilēn & until/till \\
\hline$y \bar{o} m$ & in the time (lit. in the day of) \\
\hline minyōm/minyōmā & since, when (lit. from the day of) \\
\hline Pawwalmā & as soon as (lit. from the beginning) \\
\hline
\end{tabular}

From the analysis of the data, it is evident that $\hbar a z z a t m a \overline{~ i s ~ n o t ~}$ used commonly among younger and educated speakers, whereas $s \bar{a}$ Catma $\bar{a}$ is used commonly among most speakers. wagtma $\bar{a}$ is used slightly less by older and uneducated speakers, as shown in Figures 9 and 10. All indicate similar meanings and can function similarly. They introduce the independent clause that indicates what happens immediately before the action that is mentioned in the main clause. Consider the following examples:

\begin{tabular}{|c|c|}
\hline sā $\mathbf{a} \boldsymbol{a t m} \overline{\boldsymbol{a}}$ fafathum șāhat & $\begin{array}{l}\text { "when she saw them, she } \\
\text { cried." }\end{array}$ \\
\hline kunnā hnāk wagtmā wașlō & $\begin{array}{l}\text { "we were there when they } \\
\text { arrived" }\end{array}$ \\
\hline $\begin{array}{l}\text { hiyyah mā kānat Sindah } \boldsymbol{y} \overline{\boldsymbol{o}} \boldsymbol{m} \\
\text { gālatt lah maryam }\end{array}$ & $\begin{array}{l}\text { "she was not with him } \\
\text { Maryam told him" }\end{array}$ \\
\hline
\end{tabular}




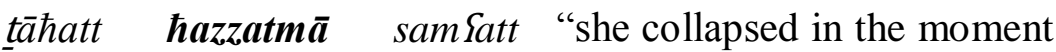
ћissah she heard him"

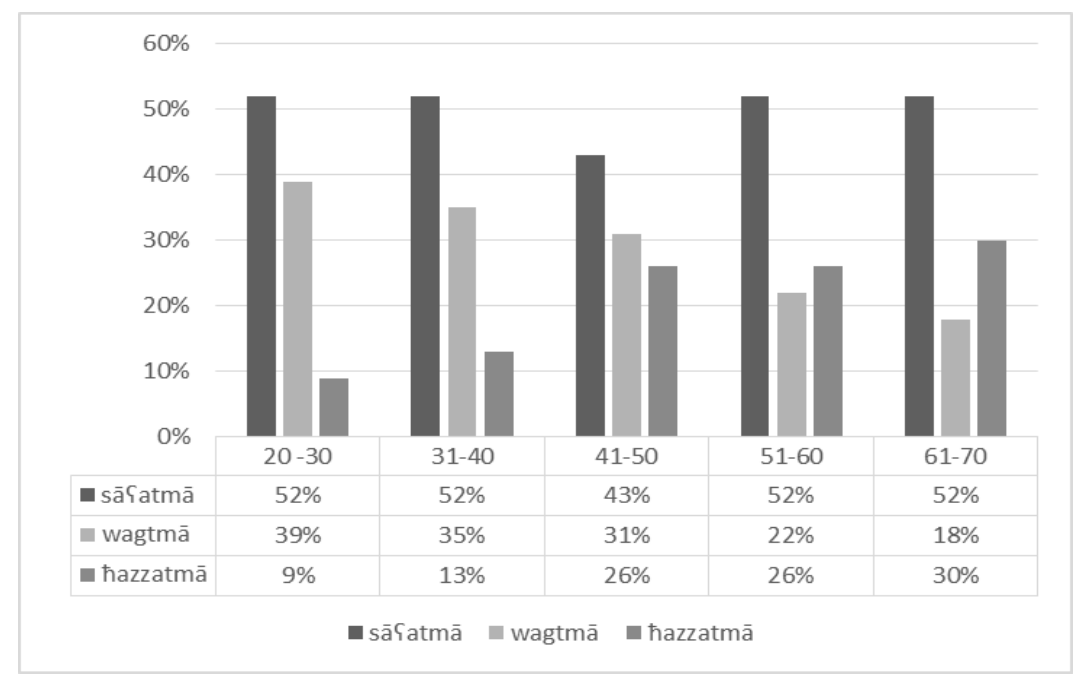

Figure 9: Average percentage of responses in which sā Satm $\bar{a}$, wagtm $\bar{a}$, and $\hbar a z z a t m \bar{a}$ are used according to age group.

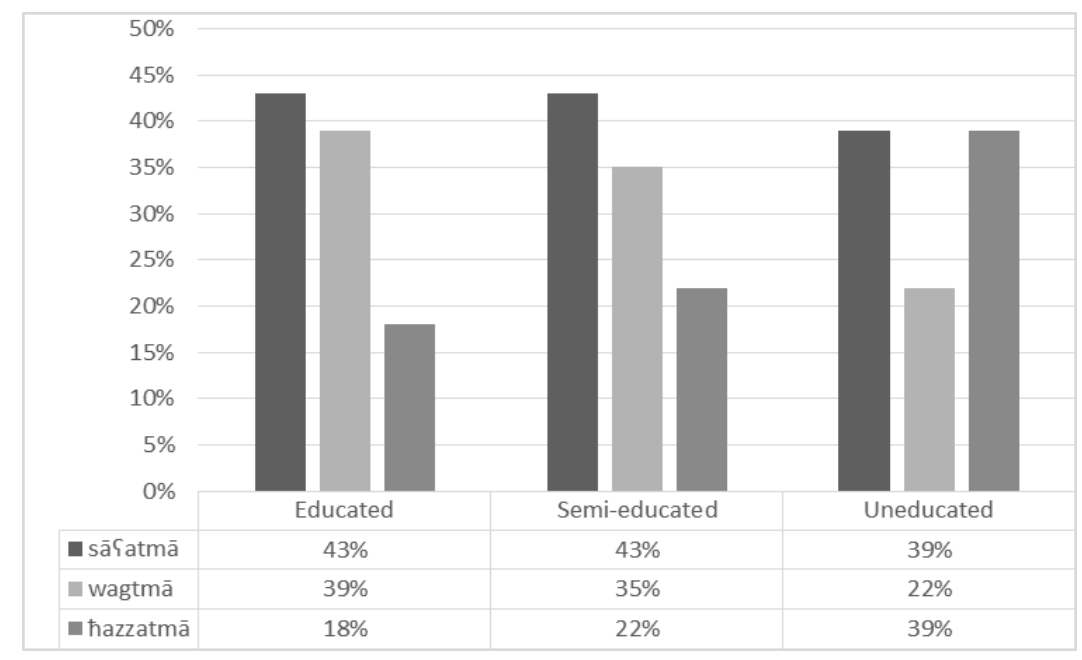

Figure 10: Average percentage of responses in which s $\bar{a}$ Satm $\bar{a}$, wagtm $\bar{a}$, and $\hbar a z z a t m \bar{a}$ are used according to level of education. 
Munira A. Al-Azraqi: Changes in conjunction usage in Abha Arabic

Some subordinators mentioned in table 5 are not changing probably because they do not have equivalent words with the same meanings and functions. These subordinators are minyōm/minyōmmā, Pawwalmā, gablmā and lèn/ilēn.

minyōm/minyōmmā means "since" and it is the only subordinator that indicates an event or action that happened before or at the time of the action expressed in the main clause. It is still used in the same sense.

$$
\begin{aligned}
& \text { mPād Juftahā minyōm "I have not seen here since } \\
& \text { taxarajat " she graduated." } \\
& \text { wallāh innahā marđat "by God, she became sick }
\end{aligned}
$$

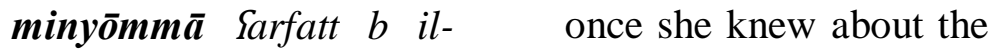

$$
\begin{aligned}
& \text { xabar } \\
& \text { news" }
\end{aligned}
$$

Pawwalmā introduces an event or action and relates it to another event or action that happened at the same time or very shortly after. It denotes the beginning of the event or action in the independent clause. gablmā, which means 'before', indicates an event or action that happened after the action expressed in the main clause. On the other hand, baSdmā indicates an event or action that happened before the action occuring in the main clause. Consider the following examples:

Pawwalmā tallaS ruxșatah "as soon as he got his license,

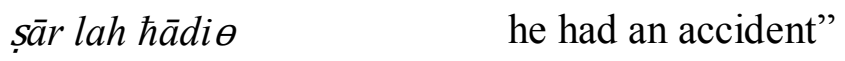

$$
\begin{aligned}
& \text { kuūl gablmā yubrud "eat before it gets cold" } \\
& \text { kānatt mā ti Srifah zèn "she did not know him well } \\
& \text { gablma tizawwajah before getting married to } \\
& \text { him" }
\end{aligned}
$$

$\boldsymbol{b a}$ Sdm $\overline{\boldsymbol{a}}$ katabat mazzagat "after she wrote, she torn the il-waragah " paper"

lèn/ilèn, which means 'until' introduces a clause that concludes 
the event indicated in the main clause. Consider the following examples:

\begin{tabular}{|c|c|}
\hline ma flēn takasar & $\begin{array}{l}\text { "he walked till he (lit. was } \\
\text { broken)" }\end{array}$ \\
\hline daggēt ilēn xadatatt ìd & $\begin{array}{l}\text { "I knocked till my hand } \\
\text { became insensitive" }\end{array}$ \\
\hline mā Siriftahā lēen jarrabtahā & $\begin{array}{l}\text { "I did not know it till I tried } \\
\text { it" }\end{array}$ \\
\hline
\end{tabular}

\subsubsection{Place}

makānmā and mahallmā are subordinators that indicate place. They introduce a clause that indicates the position or the place of the event expressed in the main clause. Consider the following examples:

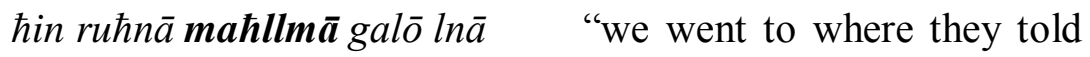

$$
\text { us." }
$$

Pālah hnāk makānmā hatatah "it is there where she put it."

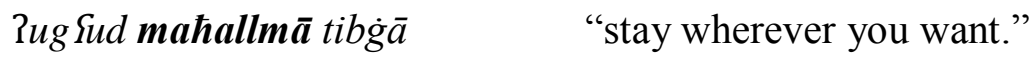

According to the results of present analysis, the variation between them in terms of usage is negligible. They are both still used, however, there is an indication that makānmā is used slightly more frequently than maћallmā by educated and younger speakers, as shown in Figures 11 and 12.

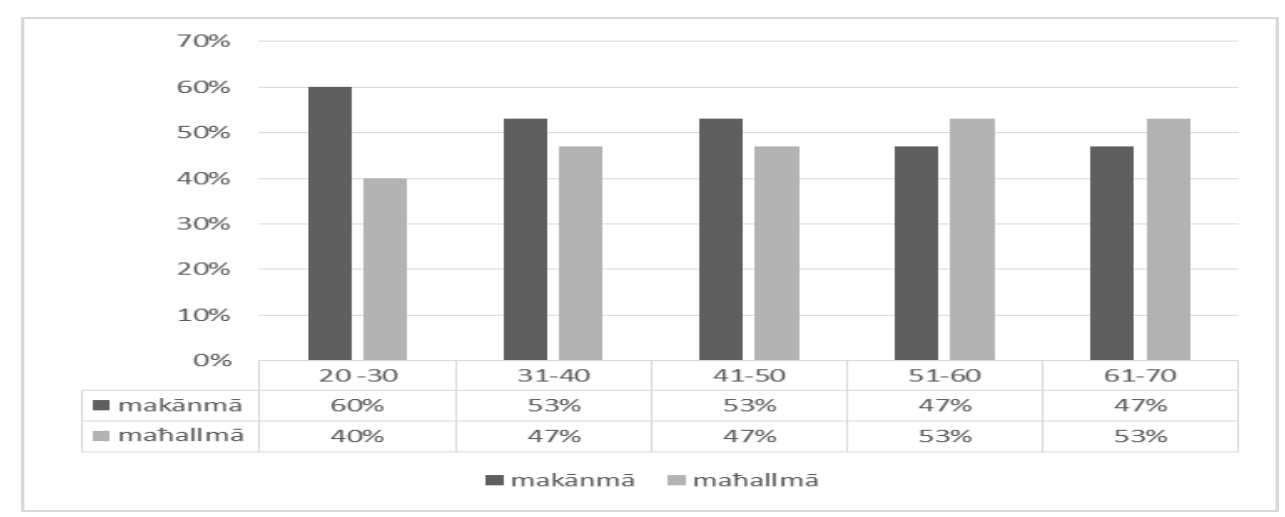


Munira A. Al-Azraqi: Changes in conjunction usage in Abha Arabic 47

Figure 11: Average percentage of responses in which

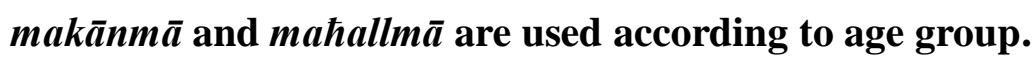

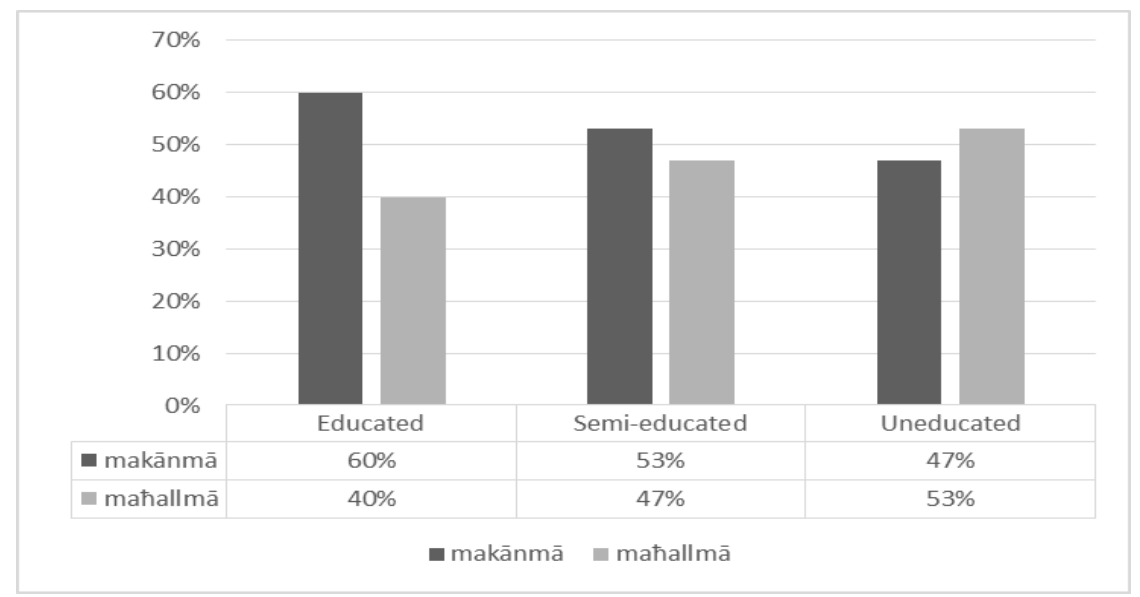

Figure 12: Average percentage of responses in which makānmā and mahallmā are used according to level of education.

\subsubsection{Manner}

The set of subordinating conjunctions mieilma $\bar{a}$, zayym $\bar{a}$, and Sala $\bar{a} \bar{a}$ introduce clauses that indicate a comparison with the ideas expressed in the main clause. They have similar meanings and can be used interchangeably in many contexts, as shown in the examples below:

$$
\begin{aligned}
& \text { Panā rasamtah zayymā gult "I drew it as you said" }
\end{aligned}
$$

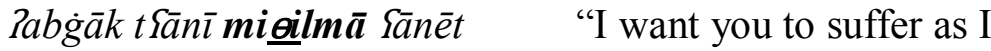

$$
\begin{aligned}
& \text { did" }
\end{aligned}
$$

mafat il-umūr Salāmā fi xātrah things have gone as in his heart (i.e. as he hoped)"

Although Galāma has the same sense as mieilmā and zayyma $\bar{a}$, the results of the analysis show that it is less frequently used and tends to be used mostly by older and uneducated people as shown in 
Figures 13 and 14.

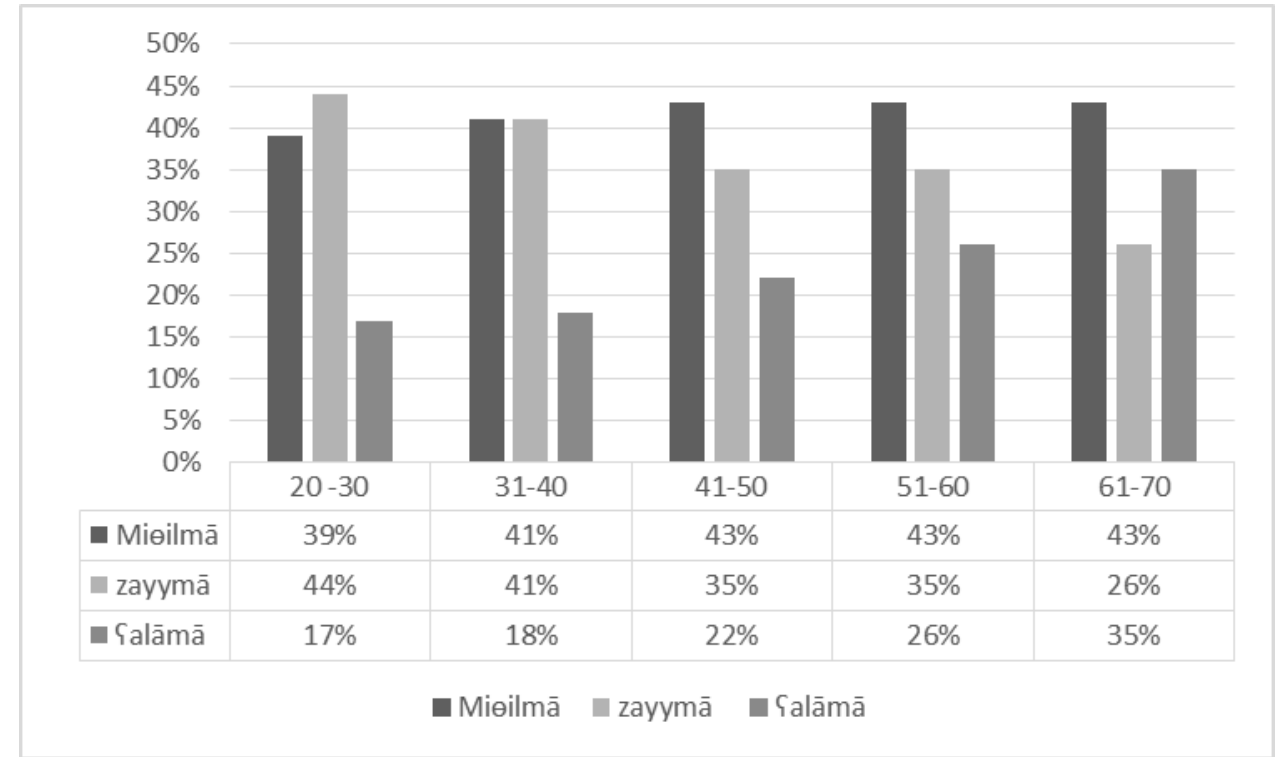

Figure 13: Average percentage of responses in which mieilmā, zayymā and Salām $\bar{a}$ are used according to age group.

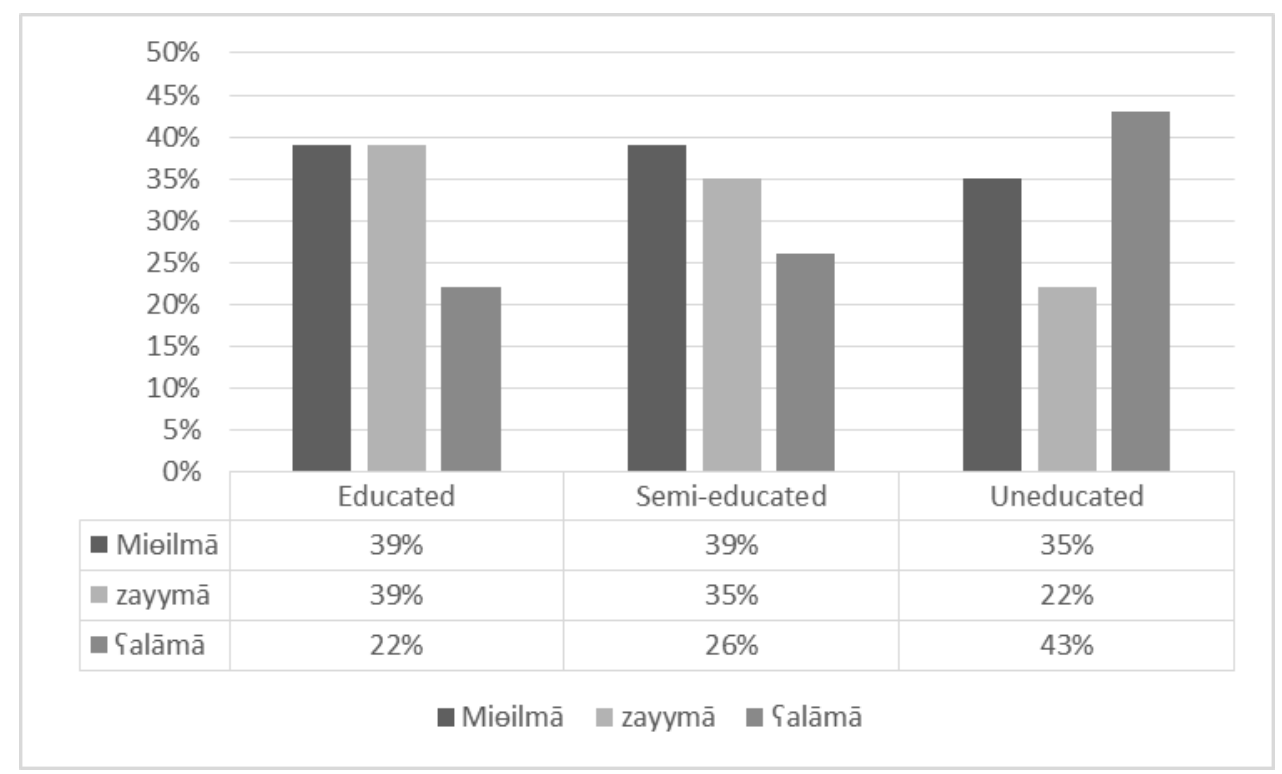

Figure 14: Average percentage of responses in which mieilmā, zayymā and Salāmā are used according to level of 
Munira A. Al-Azraqi: Changes in conjunction usage in Abha Arabic 49 education.

\subsubsection{Concession}

The subordinators in this set usually introduce clauses that contrast with the ideas in the main clause. They carry the sense of contradiction. Table 6 shows the concession subordinators along with an English translation.

Table 6: Concession subordinators in Abha dialect.

\begin{tabular}{|c|c|}
\hline Subordinator & Gloss \\
\hline ma $\operatorname{săhn}(n)$ & although/even though \\
\hline birragem min in(n) & although/in spite of \\
\hline ma ${ }^{a} \bar{a} \partial \bar{a} l i k / m a Y \bar{a} k i \underline{\partial} a h$ & however \\
\hline 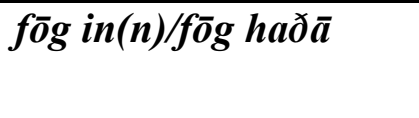 & $\begin{array}{l}\text { moreover/over } \\
\text { that/although }\end{array}$ \\
\hline $\operatorname{minsw} \bar{a} \operatorname{in}(n)$ & moreover \\
\hline
\end{tabular}

ma צä Tin and birragem min in are derived from standard Arabic without major changes. They convey the meaning of 'although' or 'even though', as shown in the following examples:

mā gid jahazaw il-awrāg $\boldsymbol{m a} \boldsymbol{\Gamma} \overline{\boldsymbol{a}}$ "they have not finished the innahā jathum min badrī papers even though they received them earlier."

biragem min inn il-kutub tabfah "although the books are a jadīdah illā inn il-manhaj new edition, the nafsah curriculum is the same.”

The results show that maYā in and birragem min in are used by 
educated and younger speakers. However, while maSā in is commonly used by most of the speakers, it seems to be preferred much more by older speakers whereas there is little difference between the two choices for the younger generations, as shown in Figures 15 and 16.

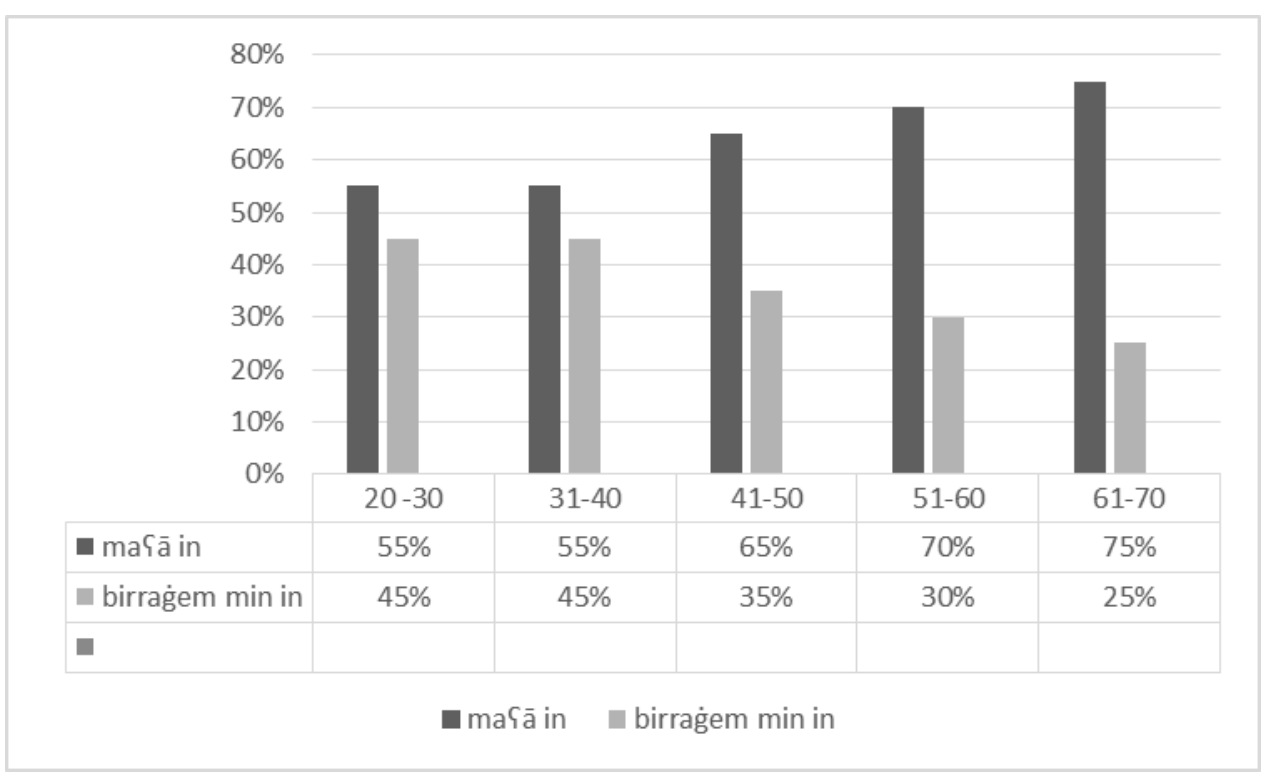

Figure 15: Average percentage of responses in which ma $\xi_{a}$ in and birragem min in are used according to age group.

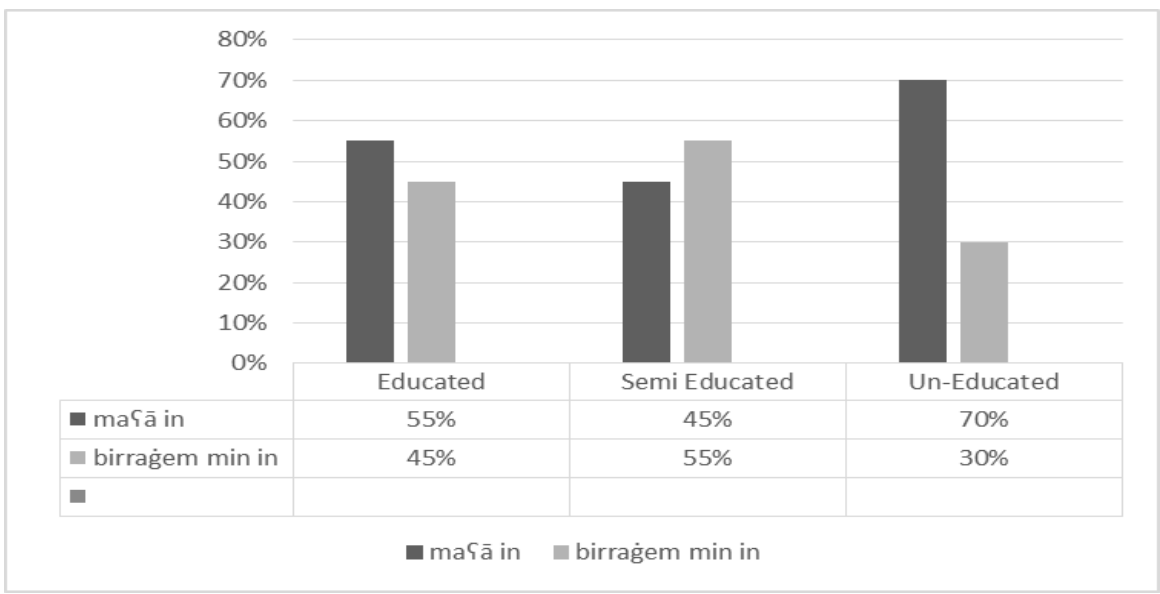

Figure 16: Average percentage of responses in which masa in and birragem min in are used according to level of 
Munira A. Al-Azraqi: Changes in conjunction usage in Abha Arabic $\underline{51}$ education.

fōg $\operatorname{in}(n) / f \bar{o} g h \bar{a} \partial \bar{a}$, and minswā inmean 'moreover' as in the following examples:

aStāh min Sindah $w \boldsymbol{f} \overline{\boldsymbol{g}} \boldsymbol{h} \boldsymbol{h} \overline{\boldsymbol{a}} \partial \overline{\boldsymbol{a}}$ yitfarrat

\section{Minswāinnah mirīđ} zād?amrađūh
"He gave him from his [money] moreover, he is asking for more"

"although he was sick they made him more sick"

Based on the results, minswa $\bar{a}$ is the form used more frequently by older and uneducated speakers, whereas younger and educated speakers use $f \bar{o} g$ in $(n) / f \bar{o} g$ hăða more frequently, as shown in Figures 17 and 18.

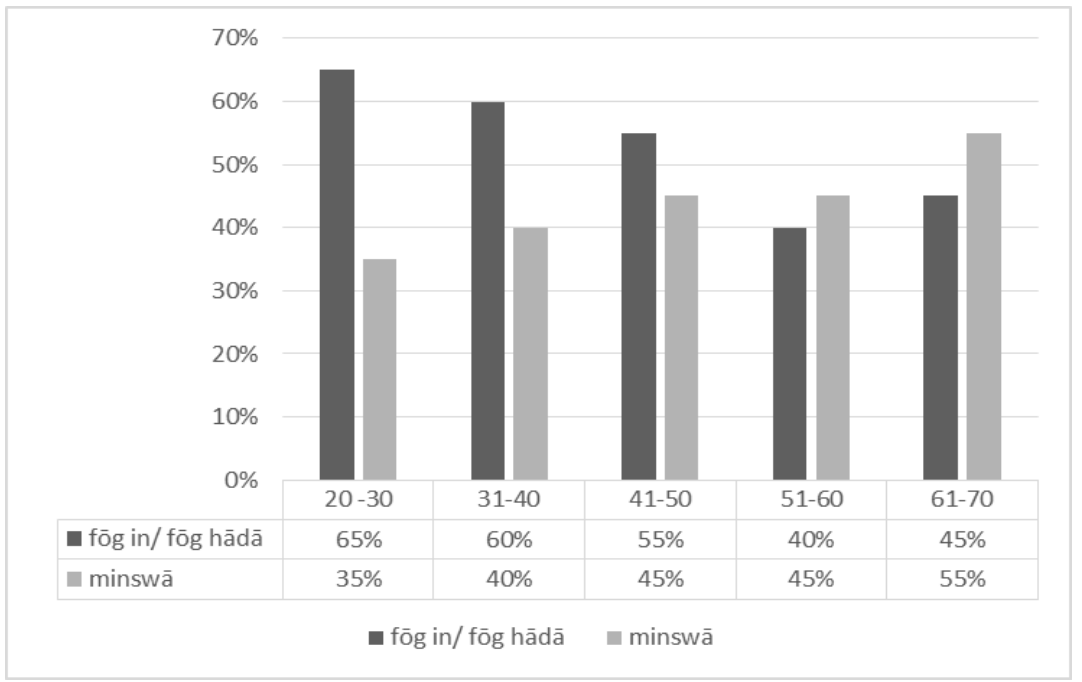

Figure 17: Average percentage of responses in which $f \bar{o} g \operatorname{in}(n) / f \bar{o} g h \bar{a} \underline{d} \bar{a}$ and $m i n s w \bar{a}$ are used by age group. 


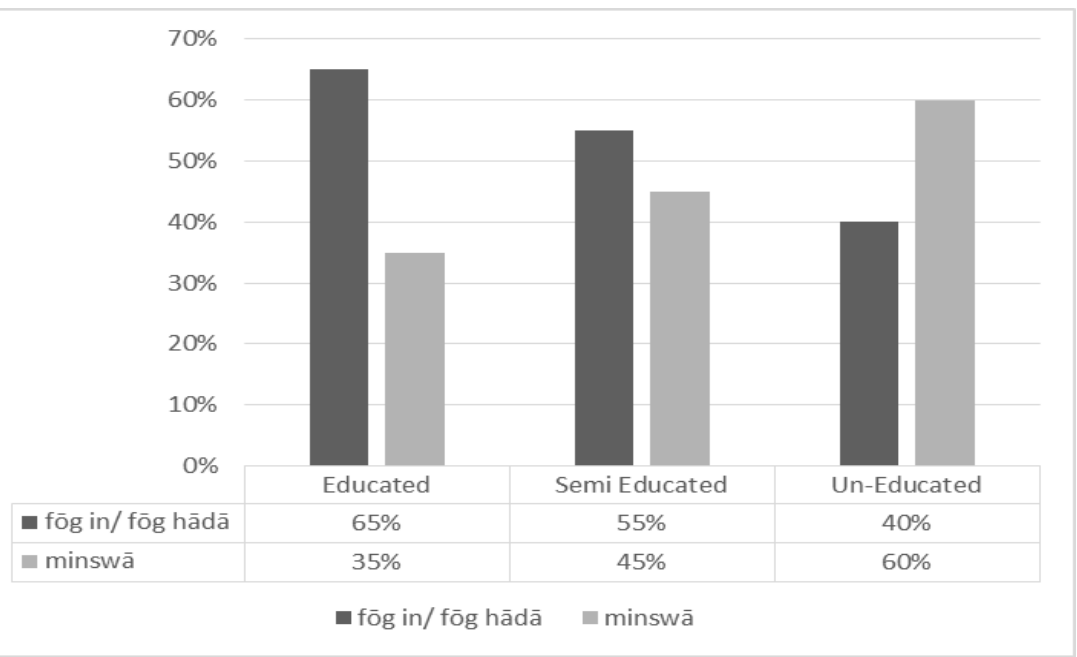

Figure 18: Average percentage of responses in which $f \bar{o} g$ in/fōg $h \bar{a} \underline{d} \bar{a}$ and $m i n s w \bar{a}$ are used according to level of education.

\subsubsection{Cause and Reason}

Clauses that provide the purpose of, or the reason for, the actions or the events indicated in the main clause in Abha dialect are introduced by the particles as indicated in Al-Azraqi (1998). See Table 7.

Table 7: Cause and reason subordinators in Abha dialect.

\begin{tabular}{|c|c|}
\hline Subordinators & Gloss \\
\hline Galafän/Gala/än in(n), minfän & for, in order to, because \\
\hline Salașirr/Galașir in $(n) / m i n s ̦ i r r$ & for, in order to, because \\
\hline $\begin{array}{l}\text { bsabab, } \quad \text { bsibb/bsibbat, } \\
\text { \{alāsibb/Salasibbat, } \\
\text { fisibb/fisibbat }\end{array}$ & because of \\
\hline $\operatorname{li} \operatorname{Tan}(n) / \operatorname{lin}(n) / \operatorname{lan}(n)$ & because \\
\hline$\hbar a t t \bar{a}$ & thus, so \\
\hline
\end{tabular}

The most common particles of this set are Salafân/ Salafânin and minfân. Morphologically, they comprise the prepositions $S a l \bar{a}$ and 
Munira A. Al-Azraqi: Changes in conjunction usage in Abha Arabic $\mathbf{5 3}$

min added to the word fan, which means 'the concern of'. They can be used in all cause and reason contexts. Similarly, Salașìr/ Salașir in(n)/minșir consist of the prepositions Sala and min beside the word sir which cannot occur freely. They mean 'for', 'in order to' or 'to'. Salāṣir/Salāșirin /minșir are the least common now and they are used in the sense of 'in order to' by older people, see Figures 19 and 20.

bsabab, bsib/bsibbat, Salāsib/Salasibbat, and fisib/fisibbat have the same sense. They are derived from the standard stem noun sabab preceded by the preposition $b$, Sala , or $f i$. The stem particle varies between $s a b a b$, sib, and $s i b+$ the feminine suffix at. Consider the following examples:

anā zurtahā Sala אân R̂nnahā bintah.

Panā mā sawètah illā Salāṣirik

$\bar{e}$ sh tibg̀ānī Pasawwī? ?askut lik

Salāșîr innik waladī?

bsibbat ða l-kūrah mafâf xēr
"I visited her because she is his daughter"

"I only did it for you"

"what do you want me to do keep quiet because you are my son?"

"because of this football, he did not do well [in his daily life]"

il-jaww härr bsabab gurb if "the weather is hot because the fams li l-ard sun is near to the earth"

According to the results shown in Figures 19 and 20, the particles, Salafan is the form which is often used by younger and educated people and less frequently by older and uneducated people. 


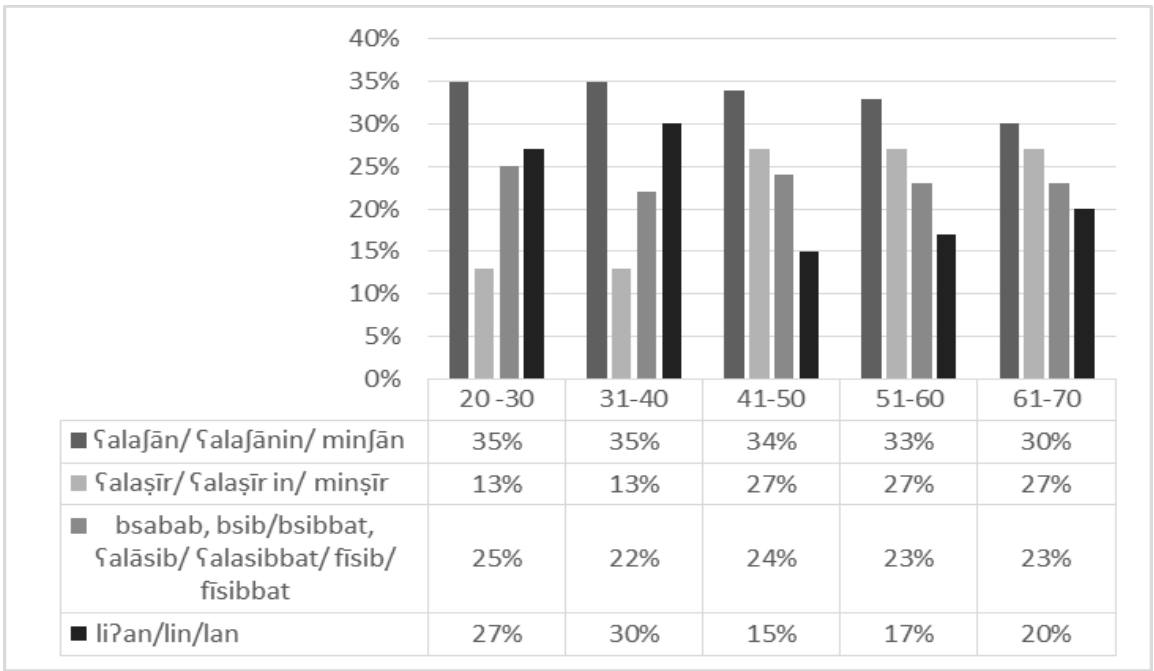

Figure 19: Average percentage of responses in which cause and reason particles are used according to age group.

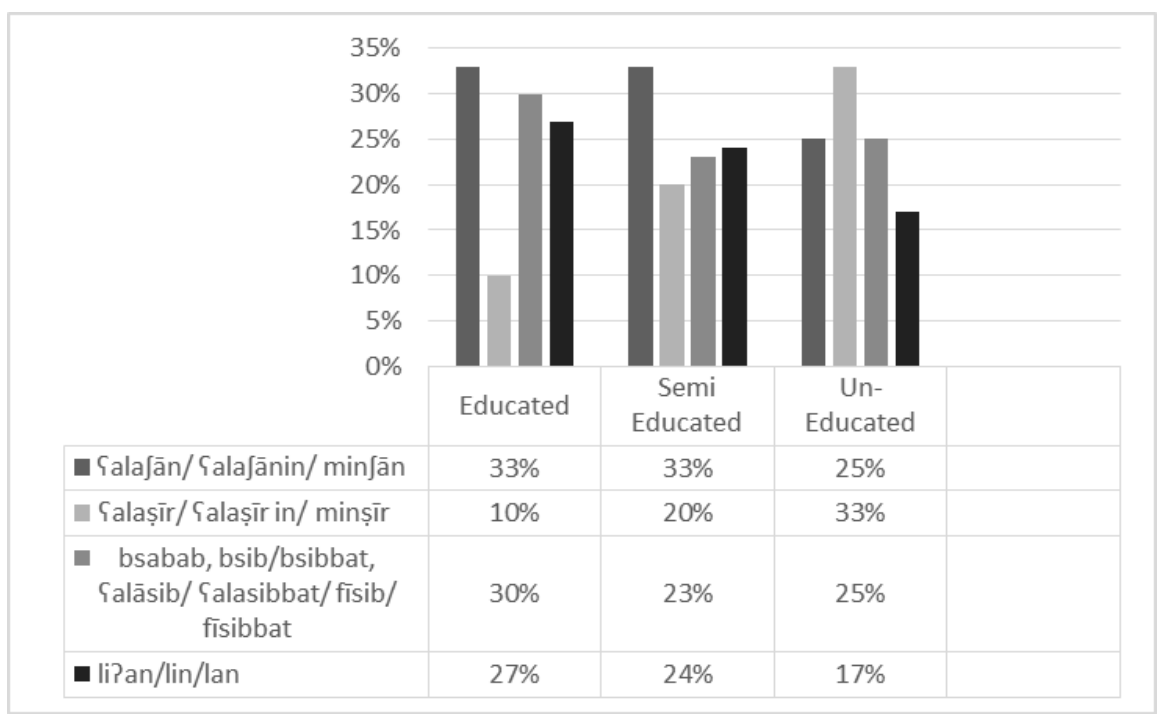

Figure 20: Average percentage of responses in which cause and reason particles are used according to level of education.

Lastly, ћattā in Abha dialect indicates cause in different ways to the other particles. That is why it is not in the chart above. The 
Munira A. Al-Azraqi: Changes in conjunction usage in Abha Arabic $\underline{55}$

subordinating clause does not express the reason for the action in the main clause; on the contrary, the main clause carries the reason for the action in the subordinating clause. Consider the following examples:

Rijlis mu Paddab hattā mā PazSal "stay polite so that I do not minnik become upset with you"

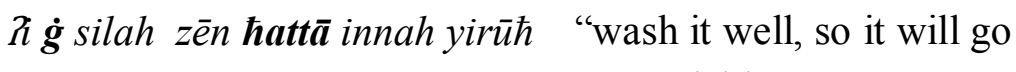
bsurfah quickly"

$\hbar a t t \bar{a}$ also has the sense of "and", "too" or "even" and can be considered as a coordinator or adverb in this case. Consider the following examples:

tidf lhum hatta $l$ walad "she prays for them
baSlahā

mā ti Srif hattā tuslug bēđah "she does not even know how to boil an egg"

ћatta is still used by all speakers regularly because it is the only particle used in the above sense.

\section{Conclusion}

As revealed by the analysis, the results in this study show that the use of conjunctions in Abha dialect varies between the older and younger generations and also between educated and uneducated speakers. This variation implies that the conjunctions preferred by the older generation will fall into disuse and may be lost completely in the coming years. This is particularly evident where there is more than one particle with the same sense and function. The preference for certain particles among the younger generation seems to be influenced by their level of education; as compared to the over 60s, most of the younger generation are educated. Because the medium of instruction is modern 
standard Arabic, the younger generation tend, sometimes, to limit their usage of the multiple variants of conjunctions and instead use those closest to modern standard Arabic.

If we look at specific examples, with respect to coordinators, $\dot{g} \bar{e} r$ is used less frequently by younger and educated speakers, who tend to replace it with $f / f a$ with the meaning of then. Also, ba den, which denotes sequence and is often used to synchronize sentences in telling stories or long events, is used by the same group of speakers more than other coordinators to replace xalf, Sawwad and eumman. Some coordinators, and despite being used in standard Arabic are not often used among younger and educated speakers such as $\dot{g} \bar{e} r$ which is used to conjoin contrastive clauses. bass, on the other hand, is a particle used in the same meaning but is used more frequently by the same group of speakers although it does not have an equivalent in standard Arabic. However, lākin is used in standard Arabic more frequently and younger and educated speakers prefer to use it more.

As for subordinators, it is clear from the results that $\hbar a z z a t m \bar{a}$ is not frequently used among younger and educated speakers, unlike sā Satmā and wagtmā. We should mention here that hazat which means 'a period of time' is not used widely in standard Arabic, but it does occur in other dialects in Najd and Al-Ahasa. Although ma $\bar{a} \overline{\text { in }}$ and birragem min in are used mostly by educated younger speakers, and mostly in formal speech, ma $\bar{a}$ in is common as well among most of the speakers. fōg in / fōg hâd $\bar{a}$ and minswā in mean 'moreover'. It was found that minswa $\bar{a}$ is the form more frequently used by older and uneducated speakers, whereas educated and younger speakers tend to use $f \bar{o} g$ in/fōg hād $\underline{a}$ more.

Conjunctions that provide the purpose of, or the reason for, the actions or the events indicated in the main clause in Abha dialect are introduced by Salafân/ Salafânin and minfân, Salașir in/ minșìr , bsabab, bsib/bsibbat, Salāsib/ Salasibbat, and fisib/fìsibbat. The results show that $b s a b a b$ is the form used mainly by younger educated people. 
Munira A. Al-Azraqi: Changes in conjunction usage in Abha Arabic $\underline{57}$

Salașir/ Galașir in/ minșir and li'an and lin seem to be the least used particles in this sense among the same group of speakers.

The new generation usually leads the way in terms of change on the linguistic level. This appears to be the case in the Abha-speaking community too. Simplification and levelling processes are taking place in this dialect (Al azraqi, 2016). Education plays a major role in the evolution of language, and in Saudi Arabia, the education sector usually focuses on a specific form of Arabic. Therefore, it would be useful to examine the content of school books as there may be inherent limitations in the Arabic used in those texts that minimizes and reduces the Arabic lexicon. To conclude, we seem to be losing a range of vocabulary such as conjunctions, even though some of their roots are related to standard Arabic. However, because they are not used widely in standard Arabic nowadays, for instance in books or other forms of media, they are becoming lost to the younger, educated generation. 


\section{Notes}

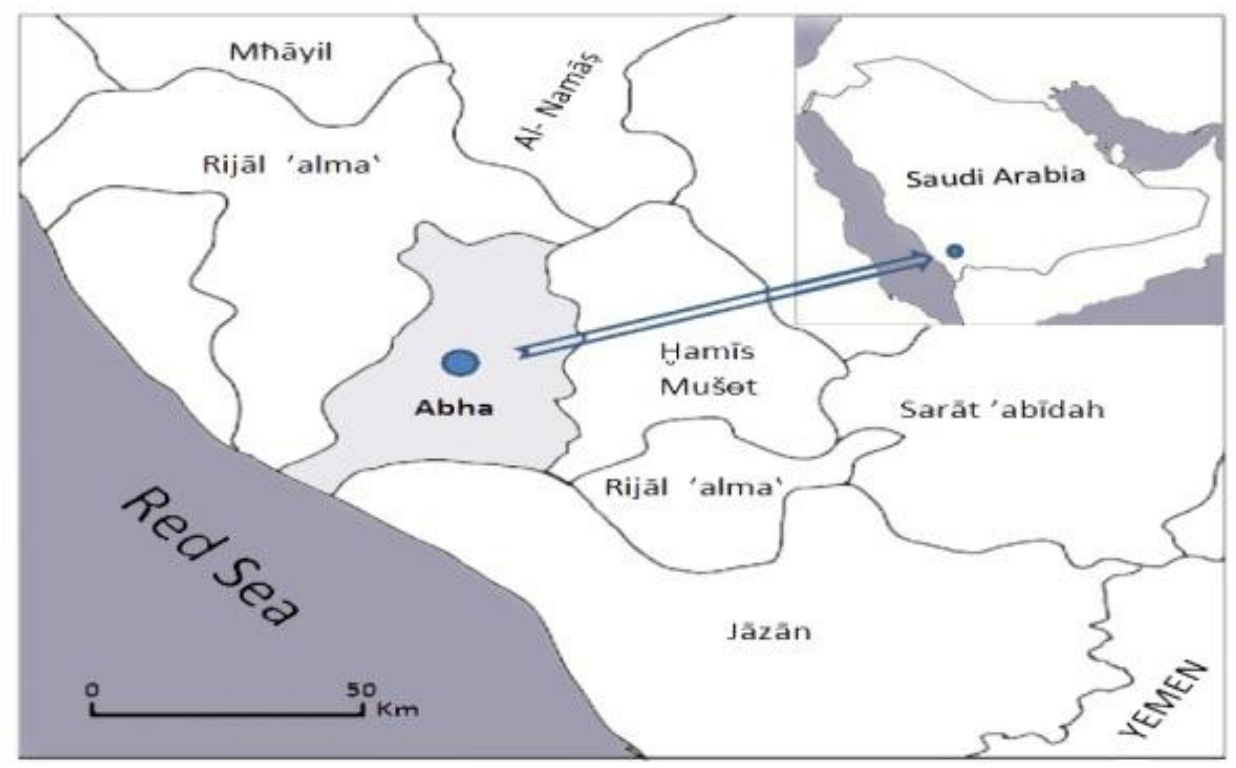

Map (1). Illustration of Abha district in relation to neighbouring districts. The inset map shows the position of Abha within Saudi Arabia. (From al-mash al-maydān̄ lil-mawāqi' wal-ḩadamāt: almințaqa al-'idāriya al-'ulā: Abha (1991). Emirate of 'Asīr, Ministry of Interior. Reproduced by the author using Adobe Illustrator CS5). 
Munira A. Al-Azraqi: Changes in conjunction usage in Abha Arabic $\underline{59}$

\section{References}

Al-Azraqi, Munira. Aspects of the syntax of the dialect of Abha (South-West Saudi Arabia), unpublished thesis, University of Durham, 1998.

Al-Azraqi, Munira. Syntactic change in the use of gid: Language contact evidence in Abha dialect, Journal of Arts, King Saud University, 2014, 26 (1), 21-29.

Al-Azraqi, Munira. A change in the usage of negators in Abha Arabic through dialect levelling. Manuscript submitted for publication, 2016.

Al-Hamadān̄̄, Al-hasan. Sifatu jazīratu al- Arab. ed. Mohammad Al -Akwa . San’a: Maktabat Al-irshād, 1983.

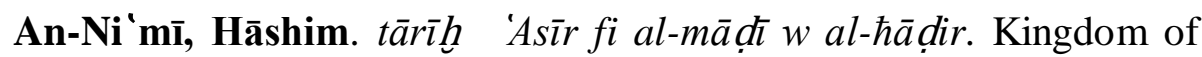
Saudi Arabia, 1999.

Az-Zamakḩsharī, Jār Allah Abū al-qāsim (died 535 AH) alMufassal fì san 'at al-i rāab, ed. by Emeely Yaqub. Beirut: Dār Alkutub al-'ilmiyah, 1999.

Badawi, E., Michael, C., Adrian, G. Modern Written Arabic: A Comprehensive Grammar. Routledge, London, 2004.

Badawi, E., Michael, C., Adrian, G. Modern Written Arabic: A Comprehensive Grammar. Routledge, London, 2004.

Britain David \& Trudgill, Petter. Migration, new-dialect formation and sociolinguistic refunctionalisation: reallocation as an outcome of dialect contact. Transactions of the Philological Society, 1999, 245-256.

Chambers, Jack \& Trudgill, Petter. Dialectology. Cambridge: Cambridge University Press, 1980.

Cowell, Mark W. A Reference Grammar of Syrian Arabic (based on the dialect of Damascus). Washington: Georgetown University Press, 1964.

Eid, M. an-naћwu al-mușaffā, Maktabat ash-shabāb, 1991.

Gibson, Maik. Dialect Levelling in Tunisian Arabic: Toward a New Spoken Standard.in Aleya Rouchdy (ed.) Language Contact and Language Conflict in Arabic; Variation on Sociolinguistic Theme. Routledge Curzon. Taylor Francis Group, 2002.

Hamzah, Fouad. fì bilādi 'Asīr. Riyadh: Maktabat Al-nasir,1968.

Hinskens, Frans. Dialect Levelling: A Two-dimensional Process. 
Folia Linguistica 1998, 32 (1-2). 35-52.

Ingham, Bruce. Najdi Arabic: Central Arabia. Amsterdam/ Philadelphia: John Benjamins, 1994.

Johnstone, Thomas. M. Some characteristics of the Dōsiri dialect of Arabic as spoken in Kuwait, Bulletin of the School of Oriental and African Studies, 1961, 24, pp 249-297.

Jrais, Ghithan. The history of Education in Assir. Abha: Dār Albilārd, 1995.

Jrais, Ghithan. .Abha: The modernized center of Assir, a documentary study. Riyadh: Al-farazdaq, 1997

Kerswill, Paul. Koineization and accommodation. in J. K. Chambers, P. Trudgill \& N. Schilling-Estes (eds.) The handbook of language variation and change. Oxford, 2002, 669-702.

Kerswill, Paul. Migration and language. In Klaus Mattheier, Ulrich Ammon \& Peter Trudgill (eds.) Sociolinguistics/ Soziolinguistik: An international handbook of the science of language and society, 2006, Vol 3

Kerswill, Paul \& Williams, Ann. New towns and koineization: linguistic and social correlates, Linguistic, 2005, 43 (5): 10231048.

Shākir, Maћmūd. shibhu jazīratu al- 'Arab (1) 'Asīr. Beirut \& Damascus: Al-maktab Al-islāmī, 1981.

Siegel, Jeff. Koines and koineization. Language in Society,1985, 14: 357-378.

Trudgill, Petter. Dialect in contact. Oxford: Basil Blackwell, 1986.

Watson, Janet C.E. A Syntax of San 'ān̄ Arabic, Wiesbaden: Harrassowitz Verlay, 1993. 